\title{
Introductory Note to the Special Issue of ICLR on the Outcome of the ILC Work on "Subsequent Agreements and Subsequent Practice in Relation to the Interpretation of Treaties"
}

\author{
Georg Nolte \\ Professor of Law, Humboldt University Berlin, Member of the ILC, Member \\ of the Institut de droit international \\ gnolte@rewi.hu-berlin.de
}

I am pleased that the International Community Law Review has, upon the initiative of Professors Malgosia Fitzmaurice and Dai Tamada, decided to devote a Special Issue to the outcome of the work of the International Law Commission (ILC or Commission) on the topic "Subsequent agreements and subsequent practice in relation to the interpretation of treaties" (SASP) - a work for which I had the privilege of serving as Special Rapporteur. I am also grateful to Professors Fitzmaurice and Tamada for inviting me to contribute an Introductory Note to this Special Issue.

At first sight, the title "Subsequent agreements and subsequent practice in relation to the interpretation of treaties" seems to describe a rather special and narrow topic. At closer inspection, however, the topic concerns a significant general question of international law, treaty interpretation, seen from a specific angle. Treaty interpretation is certainly important. But why did the Commission consider it worthwhile to work on the topic from the perspective of subsequent conduct in the application of treaties?

The answer is not straightforward. In 2007, I submitted an informal working paper entitled "Subsequent agreement and practice with respect to treaties" to the Commission's Working Group on the Long-term Programme of Work. ${ }^{1}$ The

1 Yearbook of the ILC, UN Doc. A/CN.4/SER.A/2007/Add.1 (Part 2), p. 98, at para. 374. 
introductory general part of that (unpublished) working paper outlined the reasons for the proposal to work on the topic. This part read as follows: ${ }^{2}$

\section{A. Introduction}

1. $[\ldots]$

2. It is an important question in any legal system whether and how far evolving circumstances affect existing law or obligations. This question articulates the tension between the requirements of stability and change. It is precisely the purpose of the law to provide stability in the face of evolving circumstances. On the other hand, legal systems must also leave room for the consideration of subsequent developments in order to ensure meaningful respect for the agreement of the parties, as well as for the continued fulfilment of the agreement's object and purpose.

3. International law provides certain formal procedures by which parties to a treaty can accommodate change. Parties can amend treaties, either by way of concluding an Additional Protocol, or by using a special amendment procedure that is foreseen by the treaty itself (see Articles 39-41 VCLT). Parties may also denounce a treaty under certain conditions (Article $56 \mathrm{VCLT}$ ). In extreme cases, a party may invoke a supervening impossibility of performance or a fundamental change of circumstances in order to terminate or to suspend the operation of a treaty (Articles 61 and 62 VCLT). Such mechanisms are, however, either rarely used or do not pose difficult legal problems. In most cases, the evolution of the context of a treaty must be accommodated by more informal means.

4. International law has a specific feature designed to ensure that evolving circumstances are taken into account in a way which is compatible with the agreement of the parties. This feature is referred to in Articles $3^{1}$ (3) (a) and (b) VCLT and consists of the recognition of the role that subsequent agreement and subsequent practice play in the interpretation of a treaty. Both means of interpretation are of considerable practical importance. International tribunals and other dispute settlement organs have referred to and applied Articles 31 (3) (a) and (b) VCLT in a large number of cases....

5. $[\ldots]$

C. Should the International Law Commission examine the topic of subsequent agreement and subsequent practice with respect to treaties?

6. Despite the great practical importance of the means of interpretation contained in Articles 31 (3) (a) and (b) VCLT, international tribunals have hardly ever weighed their significance beyond what the cases at hand

2 Citations omitted. 
required. In addition, these means of interpretation have rarely been the subject of extensive empirical, comparative or theoretical research. In fact, relevant subsequent agreement and subsequent practice of States is not always well-documented and sometimes only comes to light in connection with legal proceedings.

7. As important treaties reach a certain age, in particular law-making treaties of the post-1945 era, the context in which they operate becomes different from the one in which they were conceived. As a result, it becomes more likely that some of these treaties' provisions will be subject to efforts of reinterpretation, and possibly even of informal modification. This may concern technical rules or more general substantive rules. As the context of treaties evolves, they face the danger of either being "frozen" into a state in which they are less capable of fulfilling their object and purpose or of losing their foundation in the original agreement of the parties. The parties to a treaty normally wish to preserve their agreement, albeit in a manner which conforms to present day exigencies. Subsequent agreement and subsequent practice aim at finding a flexible approach to treaty application and interpretation, but one that is at the same time rational and predictable.

8. The interest in clarifying the legal significance and effect of subsequent agreement and subsequent practice is enhanced by the increasing tendency of international courts to interpret treaties in a purpose-oriented and objective manner. Before the adoption of the VCLT, it was an open question whether a more objective or more subjective method of treaty interpretation should prevail. While the VCLT already puts a stronger emphasis on objective factors, the trend towards objective treaty interpretation is continuing. The arbitral tribunal in the 2005 Iron Rhine case has, for example, maintained that an evolutive interpretation would ensure an application of the treaty that would be effective in terms of its object and purpose. The tribunal emphasized that this would "be preferred to a strict application of the intertemporal rule." At a time when international law is faced with a "proliferation of international courts and tribunals", an evolutive interpretation of treaties is, on the one hand, a method to ensure a treaty's effectiveness. On the other hand, an evolutive interpretation can lead to a reinterpretation of the treaty beyond the actual consent of the parties. This makes reference to subsequent practice less predictable and more important at the same time: it can become less predictable if the invocation of subsequent practice is not limited to elucidating the actual and continuing agreement of parties, but it can become more important when it is used as evidence of a dynamic understanding of 
treaty instruments (such as when the European Court of Human Rights speaks about the Convention as a "living instrument, which must be interpreted in the light of present day conditions").

9. Subsequent agreement and subsequent practice also affect the so-called fragmentation and diversification of international law. The Report of the ILC Study Group merely took note of the issue of subsequent practice. This may be the reason why it was suggested in 2006 in the Sixth Committee that the Commission consider the subject of adaptation of international treaties to changing circumstances, with special emphasis on the field of subsequent agreements and subsequent practice.

10. A final reason why subsequent agreement and subsequent practice as a means of interpretation of treaties should be studied results from their implications on the domestic level. In the United Kingdom, Lord Nicholls has noted in a recent decision of the House of Lords that subsequent practice would not be the right way to modify a treaty, an end which should only be achieved through an amendment procedure. In the United States, the debate on the significance of subsequent practice as a means of treaty interpretation is regarded as being part of the larger question: what effects do different sources of international law have on domestic law, and which source of international law favours a larger role of the US Senate. While the US Supreme Court has been reluctant to consider recently developed customary law in the process of interpreting international agreements, it has been more open to refer to subsequent practice in some cases. This kind of question is important for other countries as well. In Germany, for example, the Federal Constitutional Court has recently reviewed the question of whether certain informal agreements and certain practical steps taken by NATO member states are evidence of a legitimate reinterpretation of the NATO treaty, or whether these agreements must be seen as modifications of the NATO Treaty which require renewed parliamentary approval. While the German Court has, so far, held that all steps have remained within the confines of legitimate treaty interpretation by way of subsequent agreement and subsequent practice, such cases reflect a widespread concern on the side of political actors that domestic control mechanisms concerning the conclusion and application of treaties are increasingly being bypassed. A former judge of the European Court of Human Rights has described treaties as being "set on wheels" by the processes of subsequent agreement and subsequent practice.

11. $[\ldots]$

D. The goal and the possible scope of consideration of the proposed topic 
12. The goal of considering the topic of subsequent agreement and subsequent practice with respect to treaties would be twofold:

13. The first goal would be to establish a repertory of practice. Such a repertory would serve an important practical purpose. So far, the actual practice of subsequent agreement and subsequent practice with respect to treaties has never been collected in more than a random fashion. Although the importance of these means of treaty interpretation is generally acknowledged, their actual significance has not been identified in a systematic fashion, but only in judicial proceedings or when the case arose. Collecting examples of relevant subsequent agreement and subsequent practice is a value in itself, as it could form the basis of guidance in analogous cases. Although such a collection certainly could not aspire to completeness, it would nevertheless provide an exemplary overview. This would be helpful for practitioners who would then be able to reason more easily from analogy. A repertory should also provide courts and tribunals with illustrative guidance on the importance of subsequent agreement and practice. Without such guidance, judicial bodies might too early assume what they consider to be the object and purpose of the treaty, thereby potentially overlooking the continuing role of states for treaty interpretation.

14. The task of compiling the collection is not simply a matter that can be done equally well by an academic research institute. Although states do not consider it to be a secret, some subsequent agreement and practice is simply not available in the public realm. The Commission is the best possible forum to determine whether certain activities can indeed be classified as relevant practice. With the help of its members, it is also the best and most legitimate source for obtaining relevant instances of subsequent agreement and subsequent practice. Of course, the process of collecting material cannot be conducted in the style of a fishing expedition, but rather must be based on a carefully formulated questionnaire.

15. The second and more important goal of the consideration of the topic should be to derive some general conclusions or guidelines from the repertory of practice. Such conclusions or guidelines should not result in a Draft Convention, if only for the reason that guidelines to interpretation are hardly ever codified even in domestic legal systems. Such general conclusions or guidelines could, however, give those who interpret and apply treaties a sense of proportion, an orientation for the possibilities and limits of an increasingly important means of interpretation specific to international law. These conclusions, or guidelines, would neither provide a straitjacket for the interpreter, nor would they leave them in a void. They 
would provide a reference point for all those who interpret and apply treaties, and thereby contribute to a common background understanding, minimizing possible conflicts and making the interpretive process more efficient.

In 2007, most members of the ILC Working Group on the Long-term planning of work were interested in this proposal, but some were skeptical. The main concern expressed was that the proposed topic was too narrow. It was therefore suggested that its scope be broadened to "Treaties over time". This - much broader - topic would not only cover the interpretation of treaties by way of subsequent agreement and subsequent practice, but also extend, inter alia, to the elucidation of the rules of the Vienna Convention on the Law of Treaties on amendment procedures, the possibilities for denunciation and suspension of treaties (particularly by the invocation of supervening impossibility of performance and of fundamental changes of circumstances), as well as the parallel rules under customary international law. It was also considered that it would be appropriate to deal with the topic "Treaties over time" by way of a Study Group within the Commission.

The initiative to broaden the proposed topic "Subsequent agreement and practice with respect to treaties" to "Treaties over time", and to deal with it in the form of a Study Group, was not without logic. The year before, in 2006, the Commission had completed its work on Fragmentation of International Law by taking note of the conclusions of the Study Group on that topic. ${ }^{3}$ It is possible that, in 2007, some members of the ILC Working Group on the Long-term programme of work saw an analogy to this previous topic. The core of that topic had consisted in a general question of interpretation (referring particularly to article 31 , paragraph 3 (c) of the VCLT), but which extended much further than that particular provision. It is also possible that some members were skeptical because they considered that elucidating general questions of interpretation was not the usual work of the Commission, which should rather remain the progressive development and codification of international law by way of drafting conventions. This latter approach suggested that elucidatory work should rather be undertaken by way of a less formal procedure, that of a Study Group. This means that all members of the Study Group are encouraged

3 Fragmentation of International Law: Difficulties arising from the Diversification and Expansion of International Law, Report of the ILC, UN. Doc. A/61/10, p. 176, at para. 239. 
to submit papers, but that these papers are neither published as official documents nor publicly debated in plenary, and that the results of the informal debates within the Study Group are synthesized and finalized in a study by the Chairperson of the Study Group which would then be "made available on the website of the Commission and also be published in its Yearbook". 4

These considerations, while plausible to a certain extent, were not entirely convincing since, at the time the Commission had already started to work on questions relating to treaty interpretation by way of its ordinary procedure. Examples included its work, since 1993, on the topic Reservations to treaties, ${ }^{5}$ and its work, since 2004, on Effects of Armed Conflicts on Treaties. ${ }^{6}$ In addition, despite its attractive title, the topic "Treaties over time" includes a broad variety of very different complex questions which are not easy to synthesize within a general approach. And, finally, the experience of the Study Group on Fragmentation of International Law suggested that an informal method of work could lead to practical difficulties in equally involving members of the group, in involving States, and in reaching an agreed result within the Commission.

At the time, however, some members maintained their skeptical approach and, in 2008, the Commission agreed, on the basis of an extension of the original proposal of 2007 ("Treaties over time, in particular Subsequent Agreement and Practice"), ${ }^{7}$ to establish a Study Group on Treaties over time. ${ }^{8}$ From 2009 to 2012, as Chairperson of the Study Group, I submitted three reports to the Study Group on the role of subsequent agreements and subsequent practice for treaty interpretation. ${ }^{9}$ These reports contained draft conclusions which were discussed and redrafted by the members of the Study Group. The Plenary of the Commission annually took note of the work of the Study Group which was summarized in the report of the Commission. ${ }^{10}$

4

Ibid.

Reservations to Treaties, Report of the ILC, UN Doc A/66/10, p. 22, at paras. 1 et seqq.; and Add.1.

Effects of Armed Conflicts on Treaties, Report of the ILC, UN Doc. A/66/10, p. 106. Text of the proposal in Annex I, Report of the ILC, UN Doc. A/63/10, pp. 152-163.

Report of the ILC, UN Doc. A/63/10, p. 148, at para. 353 .

These reports have been published in Treaties and Subsequent Practice (G. Nolte ed.), at pp. 169-209, 210-306, and 307-386; in addition to those reports, Mr. Murase contributed a paper entitled "The pathology of 'evolutionary' interpretations: GATT article XX's application to trade and the environment" and Mr.Petrič contributed a paper on subsequent agreements and practice concerning a particular boundary treaty, see A/66/10, p. 168, at para. 338.

See Reports of the ILC, UN Doc A/64/10, pp. 148-149; A/65/10, pp. 194-195; A/66/10, pp. ${ }^{168-171 ;}$ A/67/10, pp. 77-8o. 
In 2012, at the beginning of a new quinquennium, the Commission decided to change the title and the format of the work of the Study Group. ${ }^{11}$ The change of the title from "Treaties over time" to "Subsequent agreements and subsequent practice in relation to the interpretation of treaties" implied a reduction of the scope of the topic. The change of the format meant that the work would from then on be conducted by way of the ordinary procedure of the Commission by appointing a Special Rapporteur. The Commission had thereby finally come around to accepting the original proposal of 2007. The pre-run of the topic within the Study Group on Treaties over time, however, had certainly facilitated its completion within the unusually short period of five years from 2013 to $2018,{ }^{12}$ including the continually positive and ultimately consensual reception by States. ${ }^{13}$

\section{The Role of the Commission}

The complicated history of the work of the Commission on SASP reveals an important aspect of the topic as well as of the work of the Commission more generally. The initial resistance to deal with a topic that may have appeared to be rather general and academic, and which was not even aimed at resulting in a convention, reflected more general doubts within the Commission about its proper role. However, even if such doubts sometimes continue to be expressed today, in practice the Commission has clearly moved towards accepting that "restatements" regarding general legal questions, in particular if they relate to the sources of international law, are a legitimate and important part of its work. Accordingly, in 2012, the Commission decided to put the topic "Formation and evidence of customary international law" on its active agenda (the title was later changed to "Identification of customary international law"). ${ }^{14}$ In 2015, the Commission decided to pursue the topic "Jus cogens" (the title was later changed to "Peremptory norms of general international law (Jus cogens)". ${ }^{15}$ And in 2018, the Commission put the topic "General principles of law" on its agenda. ${ }^{16}$ All these topics have in common that work on them is not supposed to result in "draft articles", and thus potentially in a convention. The

\footnotetext{
11 ILC Report A/67/10, p. 77, at para. 227.

12 In accordance with its usual practice, the Commission did not deal with the topic during its session in 2017, between first and second reading.

13 See UN Doc A/RES/73/202 of 3 January 2019.

14 ILC Report A/67/10, p. 69, at para. 157.

15 ILC Report A/7o/10, p. 138, para. 286.

16 ILC Report A/73/10, p. 299, at para. 363 .
} 
purpose of the "conclusions" resulting therefrom is rather to give some orientation to practitioners on how to identify and apply the sources of international law. ${ }^{17}$ Such work is not anymore viewed as being "merely academic", but rather its practical relevance is now generally recognized by States.

In what sense are the conclusions of the Commission on SASP (and those on the identification of customary international law, peremptory norms of general international law (jus cogens), and general principles of law) practically relevant? They are not practically relevant in the sense that they provide for ready-made and easy-to-apply solutions in concrete cases. Rather they are practically relevant as authoritative commentaries or restatements for lawyers who are faced with concrete cases. Such commentaries or restatements provide possible analogies, from the repertory of practice which they contain, and they offer a common conceptual approach which facilitates the steps of identification, structuring and working down the list of issues which may arise in a specific case. These functions of the conclusions also contribute to the improvement of the reasoning which underlies decisions and to their legitimation as expressions of an overall consistent legal system. This form of practical relevance does not necessarily accelerate the decision-making process, or the reasoning of the decision-maker, it may even force the decision-maker to be more cautious, and to take aspects into account which he or she would not have considered at first sight. It is, however, always a sign of the quality of legal reasoning if it does not jump to conclusions but takes into account all relevant considerations with a view of fitting the decision and the rule to be applied within the larger framework of the legal system.

\section{The Contributions to this Special Issue}

The different contributions to this Special Issue may be read in the light of these considerations. It is not for me to evaluate the specific analyses or propositions which are contained therein. I am, however, pleased to see that all contributions very diligently and perceptively make use of the conclusions on SASP and its commentaries. Malgosia Fitzmaurice identifies and discusses key general questions of interpretation in their light. Danae Azaria carefully analyzes and relates the jurisprudence of the ICJ and the work of the ILC regarding pronouncements of expert treaty bodies. Yukiya Hamamoto points to a crucial

17 See generally Danae Azaria, The International Law Commission's Return to the Law of Sources of International Law, Florida International University Law Review 13 (2019) pp. 989-1006. 
and increasingly important aspect of subsequent agreements and subsequent practice, the extent of their recognition under domestic (constitutional) law. Mika Hayashi closely looks at some final documents of the NPT Conference through the lens of the ILC conclusions on SASP. And, finally, Dai Tamada examines a particularly sensitive and controversial topic, the practice of the parties under the "Agreement on the Settlement of Problems concerning property and claims on economic cooperation between Japan and the Republic of Korea". 18

As will become clear when reading their contributions, the authors do not find that the conclusions on SASP are a "master key" for resolving problems of interpretation. ${ }^{19}$ At the same time, however, I do have the impression that the use by the authors of the conclusions and the commentaries on SASP makes a valuable contribution to the analysis of the problems addressed. Neither more, nor less, was the purpose of the work of the ILC on this topic.

18 UNTs, vol. 583, no. 8473, pp. 173-300.

19 This metaphor originates from, and is still relevant in, the debate on fragmentation of international law, and in particular with respect to article 31, paragraph 3 (c) VCLT, see Fragmentation of International Law: Difficulties arising from Diversification and Expansion of International Law, Report of the Study Group of the International Law Commission, Finalized by Martti Koskenniemi, A/CN.4/L.682, p. 211, at para. 42 . 